\title{
Introduction: Writing in the Anthropocene DEBORAH ROSE
}

This issue of Ecological Humanities is dedicated to a topic inspired by Val Plumwood: 'Thinking about writing for the Anthropocene'. In the last article she wrote before her death, Plumwood spoke passionately about the role of writers in our current time of crisis. She called for poets and other writers to join in a rethinking that 'has the courage to question our most basic cultural narratives'. In particular, she called for writing that is 'open to experiences of nature as powerful, agentic and creative, making space in our culture for an animating sensibility and vocabulary'. This, she says, is a major task facing the humanities today ('Nature in the Active Voice', Australian Humanities Review 46).

The articles in this issue of Ecological Humanities explore the role and dimensions of writing in this time of environmental change. They seek out the kinds of writing capable of shaking up our culture, and awakening us to new and more enlivened understandings of the world, our place in it, and the situated connectivities that bind us into multi-species communities. 